\title{
Development of Organic Fertilizer in a Livestock Business as an Alternative of Cow Manure Management Strategy
}

\author{
Sumardianto Nugroho ${ }^{1, *}$, and Suherman Suherman ${ }^{2}$ \\ ${ }^{1}$ Magister Program of Environmental Science, School of Postgraduate Studies, Diponegoro University, Semarang - \\ Indonesia \\ ${ }^{2}$ Department of Chemical Engineering, Faculty of Engineering, Diponegoro University, Semarang - Indonesia
}

\begin{abstract}
As a result of the growing population of Indonesia from year to year will affect the security of national food stocks. Demand for various types of foodstuffs will continue to increase, including beef. The growth of beef consumption per capita of Indonesian society tends to increase. During the last five years (2013-2017) the national beef cattle population shows positive growth, continuing to increase by an average of $1.54 \%$ per year. The growth of large-scale cattle farms has an impact on increasing the amount of livestock waste. The challenge of developing livestock sub-sector is to increase meat production and reduce the risk to the environment. Various kinds of waste management can be applied to livestock business before being released into the environment. Conventional end-of-pipe treatment strategies are being shifted to more profitable strategies. The processing of cattle dung manure into organic fertilizer through composting technology becomes one of the favorable alternatives. Composting is an effective method of recycling abundant livestock wastes into products that are stable, sterile, and agriculturally useful. Some technological advances in composting are essential to be applied in compensating for the production rate of cattle manure.
\end{abstract}

Keywords: Cattle manure; livestock; organic fertilizer; compost.

\section{Introduction}

Demand for various types of foodstuffs will continue to increase, including beef. The development of beef production in Indonesia period 1984 - 2017 in aggregate tends to grow positively by $2.85 \%$ per year. The production of beef in 2017 amounted to 531.76 thousand tons, up 4.95\% from 518.48 thousand tons in 2016 . Predicted beef production from 2017 to 2021 rise $9.25 \%$ per year, to 837.55 thousand tons up $13.77 \%$ from 2020 of 736.17 thousand tons. National consumption this period rise $7.55 \%$ per year, while the year 2021 is predicted at 828.36 thousand tons. The population of beef cattle in Indonesia period 1984-2017 showed a positive growth, on average increased by $1.99 \%$ per year. During the last five years (2013-2017) the national beef cattle population shows positive growth, continuing to increase by an average of $1.54 \%$ per year. In 2017 the estimated population of beef cattle Indonesia reached 16.60 million cows, or up $3.72 \%$ compared to the previous year [1].

Cattle farming in Indonesia has two important challenges in the future, namely the provision of beef stocks to meet the increasing demand for beef-based food products and the responsibility to reduce the environmental impact of cattle farming. Water and air pollution as the impact of livestock manure pollution is a major environmental challenge in the cattle business, especially on farms with cattle ownership scale large. Livestock waste, mostly manure carries a serious problem when discharged into the environment. Air pollution caused by the disposal of livestock manure is the emergence of odorous compounds and contributes to greenhouse gases (GHG). Animal manure that is dumped directly into a river or water channel will reduce the quality of water and is harmful to human health because it carries pathogens [2].

In supporting sustainable development, proper management strategies for livestock manure are needed, one of which is to realize low carbon development. Greenhouse gas emissions in livestock can be caused by microbial activity during decomposition of manure. The proper management of cattle waste manure is expected to reduce its contribution to greenhouse gas emissions. Storage, handling, and improper use of cow manure in farming systems can have a negative impact on the environment [3].

\footnotetext{
* Corresponding author: zumar183@yahoo.co.id
} 


\section{Effects of animal manure from cattle breeding farms on the environment}

The total live weight of cattle, type, size and age are factors that influence the amount and composition of cattle manure, besides that animal feed, livestock management, and climate also influence [4]. Taiganides [5] has provided guidelines that can be used in planning to determine the magnitude of the parameters of cattle waste as the basis for calculation is the total life weight of livestock (TLW), as can be seen in Table 1. The amount of livestock waste managed can be greater than the values presented in the table, this can be due to the amount of water used to handle the manure and the material absorbing moisture and litter [4].

Table 1. Bioengineering parameters of feedlot beef [5].

\begin{tabular}{|c|c|c|}
\hline Parameters & Units & $\begin{array}{c}\text { Feedlot } \\
\text { beef }\end{array}$ \\
\hline Wet waste (TWW) & \%TLW/day & 3.6 \\
\hline \multirow{2}{*}{ Total solids (TS) } & \%TWW & 29.7 \\
\cline { 2 - 3 } & \%TLW/day & 1.07 \\
\hline $\begin{array}{c}\text { Biochemical } \\
\text { oxygen } \\
\text { demand (BOD } 5)\end{array}$ & \%TS & 8.8 \\
\cline { 2 - 3 } & \%TL/day & 0.09 \\
\hline $\begin{array}{c}\text { Total } \\
\text { Nitrogen (N) }\end{array}$ & \%TLW/day & 0.043 \\
\cline { 2 - 3 } \begin{tabular}{c} 
Phosphate $\left(\mathrm{P}_{2} \mathrm{O}_{5}\right)$ \\
\cline { 2 - 3 }
\end{tabular} & \%TLW/day & 0.015 \\
\cline { 2 - 3 }
\end{tabular}

Livestock slurry has a lower $\mathrm{N}$ content than commercial fertilizers, while $\mathrm{P}$ and $\mathrm{K}$ elements have equivalent values for mineral fertilizers. The application of the slurry can have a negative impact on the environment if it is applied higher than the absorption capacity of the plant. Nutrient runoff and leaching can cause pollution in surface and ground water. Water pollution as a result of inappropriate manure application on agriculture and direct disposal to the waters will have an impact on the increasing need for water purification for drinking water supply [6].

\section{Cattle manure management}

In terms of cattle manure is something that is dirty and cause perception as a disgusting object, unpleasant to look at, and cause odor. Along with the times, the development of agricultural technology, and public awareness of the environment then there is a change in the treatment of cattle manure for the better.
Initially, the environmental management strategy refers to the carrying capacity approach, but on a concept that is quite difficult to implement. This is due to the existence of factors, such as environmental conditions that become polluted and damaged due to the high cost. As time passes, the concept of environmental management strategy turns into a problem-solving effort with end-of-pipe. End-of-pipe treatment has the expectation of environmental quality can be improved even though in fact the problem of environmental pollution is still going on [7].

According to UNEP, clean production is a preventive and integrated environmental management strategy that needs to be applied continuously to the production process and product life cycle with the aim of reducing risks to humans and the environment. The focus of clean production is to manage for elimination and minimization of waste generated from the source rather than using an end-of-pipe treatment strategy [8].

Current legislation on solid waste management is emphasizing the importance of recycling and recovering in the management of solid organic waste to replace conventional management such as landfill and incineration. Composting as biological treatments is a good alternative for the management of solid organic waste [9]. Managing organic waste through composting can reduce the cost of disposal of by-products and residues and can also provide income because compost is a product that has good physical and chemical properties for soil enhancers [10].

\section{The composting of cattle manure into organic fertilizer}

Processing of cattle manure into organic fertilizer through composting is an environmentally friendly production process with aerobic processes and damage to pathogens and weeds. Composting supports circular agriculture systems because through composting it can be possible to stabilize organic waste and produce organic fertilizers to be used as soil conditioners in agricultural land [11].

\subsection{Composting technologies}

Windrows, aerated static piles, and in-vessel systems are common composting technologies for processing cattle manures.

Windrow composting method is simple conventional composting system but much in demand because of easy in the implementation. Compost materials are piled in long lines and then reversed or rotated periodically to increase porosity, oxygen supply, reduce humidity, and even out the temperature of the pile [12].

The next composting technique is aerated static piles which consist of passively aerated windrow systems or also called static pile natural ventilation and forced aerated static piles. The equation of the two composting techniques is the placement of perforated pipes in the bottom of the pile to help air flow throughout the pile. 
While the difference is the supply of air in forced aerated static piles assisted with the installation of a blower at the end of the pipe. Mixing of composting raw materials before air pipe installation is one of the keys to the success of these two systems [13].

In-vessel systems are composting techniques that use cylindrical solid-state bioreactors. In this composting system makes it easy for the implementation of the monitoring and control of parameters such as temperature, humidity, and air supply. However, for large-scale material composting, there is difficulty in controlling the operating parameters caused by the emergence of hydrodynamic constraints when the size increases. Research in the laboratory and on a pilot scale prefer to use in-vessel systems [12].

\subsection{Composting process}

In the composting process consists of four phases, are as follows [12]:

- The temperature that occurs during the mesophilic phase is between $15-35^{\circ} \mathrm{C}$. In this phase there is an initial breakdown of compost material carried out by mesophilic microorganisms by utilizing the compound content of soluble and easily assimilated compost organic matter such as lipids, amino acids, and sugar.

- In the second phase called the thermophilic phase occurs at an increase in temperature between $65-85$ ${ }^{\circ} \mathrm{C}$ followed by a reduction in pathogenic agents and seeds that can germinate. There is a change in the population of mesophilic microorganisms that are less competitive by thermophilic microorganisms.

- The next phase is cooling with a decreasing temperature in the range of $15-35^{\circ} \mathrm{C}$.

- In the end the maturation phase occurs with the result is the formation of humic substance precursors.

\subsection{Control parameters in composting}

Process monitoring of composting cattle manure can be done on routine variable. There are several factors that influence the effectiveness of the composting process, as follows:

- The $\mathrm{C} / \mathrm{N}$ ratio of 30-35: 1 is the recommended value for the characteristics of the initial mixture of raw materials with the aim of ensuring microorganisms can decompose and convert organic matter in the right conditions [12]. The $\mathrm{C} / \mathrm{N}$ ratio of various compost materials are shown in Table 2.

- Moisture content (MC) from the composting material mixture is recommended in the range of 55$65 \%$ [12] because it affects the temperature during the composting process, oxygen absorption, free air space, and microbial activity [14].

- The particle size of the composting material has an effect on good porosity quality to provide optimal aeration [14].

- The temperature during the composting process should not be more than $60-65^{\circ} \mathrm{C}$, this can cause the composting process to stop due to the killing of almost all participating microorganisms [14].

- The optimum $\mathrm{pH}$ values range from 5.5 to 8 [15].

- Turning frequency during the composting process has a relationship with some compost maturity measurement parameters such as temperature, MC, $\mathrm{pH}$, and $\mathrm{C} / \mathrm{N}$ ratio [14].

- Aeration is needed in the composting process because essentially composting is an aerobic process so that its efficiency also depends on the level of $\mathrm{O}_{2}$ obtained. The survival of microorganism populations in composting processes also depends on the level of $\mathrm{O}_{2}$ supplied [14]. Aeration can be done using an air blower [16] or with consideration of cost and energy savings, aeration systems can also be done naturally [17].

- Electrical conductivity (EC) for applications in agriculture is lower than $2.5 \mathrm{mS} / \mathrm{cm}$ [18], while ideal compost is lower than $2.0 \mathrm{mS} / \mathrm{cm}$ [19]

Table 2. The $\mathrm{C} / \mathrm{N}$ ratio of various compost materials $[4,20]$

\begin{tabular}{|l|c|}
\hline \multicolumn{1}{|c|}{ Materials } & C/N ratio \\
\hline Cow manure & 18 \\
\hline Non legume vegetable waste & 11 to 12 \\
\hline Grass clippings & 12 to 15 \\
\hline Mixed grasses & 19 \\
\hline Saw dust & 200 to 500 \\
\hline Straw, oats & 48 \\
\hline
\end{tabular}

\section{Discussion}

Composting is the right choice in tackling cattle breeding waste because the process has produced more useful output from something that was once dirty and disgusting. Some cattle breeding in Indonesia manage livestock manure into organic fertilizer in the same location as their business. The main problem faced is the more number of cattle owned, the more manure is produced per day. This is a challenge in terms of composting cattle breeding waste.

The composting process usually takes a long time but the development of composting technology can help shorten the composting time [14]. The choice of the composting method to be used can be adjusted with capital, costs, land, compost raw materials and composting plan time [21].

\subsection{Optimization of composting raw materials}

Based on some previous statements, it is necessary to plan for composting cow manure with reference to low $\mathrm{C} / \mathrm{N}$ ratio that is $18: 1$ and other parameters that need to be optimized.

To improve the characteristics of the main organic matter composting such as cow manure, it can be added 
to bulking agents such as sawdust and / or rice husk which aims to increase the $\mathrm{C} / \mathrm{N}$ ratio and porosity conditions before the composting process is carried out [14]. The $\mathrm{C} / \mathrm{N}$ ratio has a relationship to the length of time for aerobic composting like: compost material with $\mathrm{C} / \mathrm{N}$ ratio $20: 1$ has composting time about 12 days; compost material with $\mathrm{C} / \mathrm{N}$ ratio $20: 1-50: 1$ has composting time about 14 days; and compost material with $\mathrm{C} / \mathrm{N}$ ratio $=78: 1$ has composting time about 21 days $[4,22]$.

\subsection{Inoculation needs}

The process of composting organic matter can actually take place naturally. In the advancement of technological development and composting research, there are reports stating that increasing the rate of degradai organic matter can be done by adding inoculating agents [23].

At the moment has a lot of inoculating agents or bioactivator that is produced commercially and are already available on the market, among others are EM-4, OrgaDec, StarDec, Boisca/ Propuri, and Promi with different acceleration results due to the composting conditions.

\subsection{Selection of composting technology}

The optimal composting process can be achieved by selecting the right technology so that it is expected to achieve an effective production process time, cost efficiency, organic fertilizer results that comply with the standards of applicable organic fertilizer regulations and have little impact on the environment.

For example, forced aeration static pile composting techniques can take place faster than static pile natural ventilation and can reduce $\mathrm{N}$ loss from volatilization [21].

\section{Conclusion}

The growth of cattle breeding business has brought good results in supporting the national economic development especially in the livestock sub-sector. Livestock activities in addition to producing useful products also provide product output in the form of waste. Cattle farming in Indonesia has two important challenges in the future, namely the provision of beef stocks to meet the increasing demand for beef-based food products and the responsibility to reduce the environmental impact of cattle farming.

Application of composting method of cow livestock waste from something dirty and disgusting into organic fertilizer that is beneficial to other development sectors such as agriculture is an appropriate step that reflects the cleaner production in a cattle breeding business. Composting of cattle manure into organic fertilizer is the application of the principle of reduce and recycle in sustainable waste management in line with the concept of zero waste.
The current and future challenges are the greater demand for beef production to impact on the increase in the cattle population so that the amount of waste that must be processed through composting is increasing. The cattle farmers can increase compost production by optimizing the parameters in the composting process such as optimizing raw materials and its supporters and application of composting technology in accordance with the availability of land.

\section{References}

1. Kementerian Pertanian: Outlook Daging Sapi. Pusat Data dan Sistem Informasi Pertanian, Jakarta (2017)

2. Shen, Y., Tan, M.T.T., Chong, C., Xiao, W., Wang, C.: An Environmental Friendly Animal Waste Disposal Process with Ammonia Recovery and Energy Production: Experimental Study and Economic Analysis. Waste Manag. 68, 636-645 (2017)

3. Alberta: Manure Management and Greenhouse Gases. , Canada (2004)

4. Polprasert, C.: Organic Waste Recycling Technology and Management. IWA Publishing, Bangkok (2007)

5. Taiganides, E.P.: Energy and Useful by Product Recovery from Animal Wastes. In: Water Pollution Control in Developing Countries. pp. 315-323. Asian Institute of Technology, Bangkok (1978)

6. Hjorth, M., Christensen, K.V., Christensen, M.L., Sommer, S.G.: Solid-Liquid Separation of Animal Slurry in Theory and Practice. A Review. Agron. Sustain. Dev. 30, 153-180 (2010)

7. Indrasti, N.S., Fauzi, A.M.: Produksi Bersih. IPB Press, Bogor (2009)

8. Filho, M.G., Nunhes, T.V., Barbosa, L.C.F.M., de Campos, F.C., de Oliveira, O.J.: Opportunities and Challenges for the Use of Cleaner Production to Reduce Water Consumption in Brazilian SugarEnergy Plants. J. Clean. Prod. 186, 353-363 (2018)

9. Mejias, L., Komilis, D., Gea, T., Sánchez, A.: The Effect of Airflow Rates and Aeration Mode on the Respiration Activity of Four Organic Wastes: Implications on the Composting Process. Waste Manag. 65, 22-28 (2017)

10. Proietti, P., Calisti, R., Gigliotti, G., Nasini, L., Regni, L., Marchini, A.: Composting Optimization: Integrating Cost Analysis with The PhysicalChemical Properties of Materials to be Composted. J. Clean. Prod. 137, 1086-1099 (2016)

11. Cáceres, R., Malińska, K., Marfà, O.: Nitrification Within Composting: A Review. Waste Manag. 72, 119-137 (2018)

12. Sánchez, Ó.J., Ospina, D.A., Montoya, S.: Compost Supplementation with Nutrients and Microorganisms in Composting Process. Waste Manag. 69, 136-153 (2017)

13. Cooperband, L.: The Art and Science of Composting: A resource for Farmers and Compost 
Producers. (2002)

14. Onwosi, C.O., Igbokwe, V.C., Odimba, J.N., Eke, I.E., Nwankwoala, M.O., Iroh, I.N., Ezeogu, L.I.: Composting Technology in Waste Stabilization: On The Methods, Challenges and Future Prospects. J. Environ. Manage. 190, 140-157 (2017)

15. Chen, Z., Zhang, S., Wen, Q., Zheng, J.: Effect of Aeration Rate on Composting of Penicillin Mycelial Dreg. J. Environ. Sci. 37, 172-178 (2015)

16. Lazcano, C., Gómez-Brandón, M., Domínguez, J.: Comparison of the Effectiveness of Composting and Vermicomposting for the Biological Stabilization of Cattle Manure. Chemosphere. 72, 1013-1019 (2008)

17. Oudart, D., Robin, P., Paillat, J.M., Paul, E.: Modelling Nitrogen and Carbon Interactions in Composting of Animal Manure in Naturally Aerated Piles. Waste Manag. 46, 588-598 (2015)

18. Mulec, A.O., Mihelič, R., Walochnik, J., Bulc, T.G.: Composting of the Solid Fraction of Blackwater from a Separation System with Vacuum ToiletsEffects on the Process and Quality. J. Clean. Prod. 112, 4683-4690 (2016)
19. Turan, N.G.: The Effects of Natural Zeolite on Salinity Level of Poultry Litter Compost. Bioresour. Technol. 99, 2097-2101 (2008)

20. Golueke, C.G.: Composting: A Study of the Process and Its Principles. Rodale Press, Pennsylvania (1972)

21. Rasapoor, M., Adl, M., Pourazizi, B.: Comparative Evaluation of Aeration Methods for Municipal Solid Waste Composting from The Perspective of Resource Management: A Practical Case Study in Tehran, Iran. J. Environ. Manage. 184, 528-534 (2016)

22. Haug, R.T.: Compost Engineering: Principles and Practice. Ann Arbor Science, Michigan (1980)

23. Cerda, A., Artola, A., Font, X., Barrena, R., Gea, T., Sánchez, A.: Composting of Food Wastes: Status and Challenges. Bioresour. Technol. 248, 57-67 (2018) 